\title{
Pengaruh Disiplin Belajar dan Minat Siswa terhadap Hasil Belajar Pendidikan Agama Islam di SMA N 1 Panyabungan Selatan Kabupaten Mandailing Natal
}

\author{
Rohimah Nur Nasution \\ AKPAR Paramitha Bukittinggi \\ Email: rohimahnasution5@gmail.com
}

\begin{abstract}
This research in a type of quantitative research. The population in this study were all students of class X and XI in SMAN 1 Panyabungan Selatan amounting to 152 people. Sampling is done by sampling technique used is proportional stratified random sampling. The number of samples in this study were 60 students. The instrument used was a questionnaire. Data were analyzed using multiple linear regression analysis techniques. The findings of this study indicate that 1) The influence of learning discipline on student learning uotcomes in SMAN 1 Panyabungan Selatan. The value of regression coefficient is $25 \%$. Positive coefficient means that there is a positive influence between learning discipline an student learning outcomes, the better the discipline of student learning, the better student learning uotcomes, 2) The influence of student learning interest on learning outcomes in SMAN 1 Panyabungan Selatan. Based on regression coefficient of $46 \%$. Positive coefficient means that there is positive influence between learning interest an student learning outcomes, the better the discipline of student learning, the better student learning uotcomes, 3) The influence of learning discipline and student interest in learning outcomes of Islamic religious education in SMAN 1 Panyabungan Selatan. Learning discipline and interest in learning together have a positive and significant outcomes in SMAN 1 Panyabungan Selatan.
\end{abstract}

Keyword: Learning Discipline, Student Interest and Learning Outcomes

\section{Pendahuluan}

Pendidikan merupakan suatu proses yang sangat penting dan tidak bisa lepas dari kehidupan manusia. Pendidikan ini harus terus berjalan untuk menjaga keberlangsungan hidup manusia, karena tanpa pendidikan tidak akan ada perpindahan ilmu pengetahuan serta nila-nilai dan norma sosial dari generasi tua ke generasi muda. Pendidikan adalah usaha sadar dan bertujuan untuk mengembangkan kualitas manusia sebagai suatu kegiatan yang sadar akan tujuan. Aktivitas dalam mendidik yang merupakan suatu pekerjaan memiliki tujuan dan ada sesuatu yang hendak dicapai dalam pekerjaan tersebut, maka dalam pelaksanaannya berada dalam suatu proses yang berkesinambungan di setiap jenis dan jenjang pendidikan, semuanya berkaitan dalam suatu system pendidikan yang integral. Keberhasilan pendidikan bukan hanya menjadi tanggung jawab pemerintah saja, tetapi menjadi tanggung jawab seluruh bangsa Indonesia.Peran serta masyarakat sangat menentukan keberhasilan pendidikan. Proses pendidikan berlangsung di keluarga, masyarakat dan sekolah. Sekolah sebagai lembaga pendidikan formal merupakan tempat

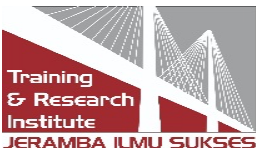


kegiatan belajar mengajar yang bertujuan meningkatkan kualitas anak didik. Dalam proses belajar mengajar terlihat adanya rangkaian kegiatan yang menyeluruh menyangkut berbagai faktor, sehingga berhasil atau tidaknya proses belajar mengajar tergantung pada faktor-faktor yang mempengaruhinya. Faktor-faktor yang mempengaruhi proses belajar mengajar adalah faktor internal dan eksternal. Faktor internal merupakan faktor yang berasal dari individu yang bersangkutan, anatara lain meliputi keadaan jasmani (fisik) dan rochani (psikis). Sedangkan faktor eksternal merupakan faktor yang berasal dari luar individu yang bersangkutan atau yang sering disebut sebagai faktor lingkungan.

Faktor lain yang dapat mempengaruhi kegiatan belajar adalah disiplin belajar. Baik itu disiplin belajar di sekolah maupun di rumah. Disiplin belajar di rumah, antara lain meliputi : belajar setiap hari, mengerjakan pekerjaan rumah, membuat laporan, belajar berkelompok dan sebagainya. Sedangkan disiplin belajar di sekolah antara lain meliputi: ketepatan waktu datang ke sekolah, keaktifan mengikuti pelajaran di kelas, ketaatan mengikuti peraturan di kelas maupun sekolah, menggunakan waktu luang dan sebagainya. Seorang siswa perlu memiliki sikap disiplin dengan melakukan pelatihan yangmemperkuat dirinya sendiri untuk selaluterbiasa patuh dan memiliki kendali diri,disiplin belajar adalah pengendalian dirisiswa terhadap bentuk-bentuk aturan baiktertulis maupun tidak tertulis yang telah diterapkan oleh siswa yang bersangkutanmaupun berasal dari luar serta bentukkesadaran akan tugas dan tanggungjawabnya sebagai pelajar, baik disiplin dirumah maupun di sekolah dengan tidakmelakukan sesuatu yang dapat merugikantujuan dari proses belajarnya. Tingkat disiplin belajar sesorang anak dapat membawa anak tersebut memperoleh prestasi belajar yang tinggi. Bila seoranganak kurang memiliki disiplin dalambelajar, maka dapat dikatakan anak tersebut kurang memiliki keseriusan dalam belajar dan akan berdampak pada situasi belajarnya yang menurun.

Menurut Benhard disiplin diri adalah mengupayakan pengembangan minatanak dan mengembangkan anak menjadi manusia yang baik, yang akan menjadisahabat, tetangga, dan warga negara yang baik Disiplin adalah ketaatan atau kepatuhan yaitu ketaatan seseorang terhadap tatatertib atau kaidah-kaidah hidup lainnya. Dengan demikian ketertiban danketeraturan dalam belajar tidak terwujud secara tiba-tiba, melainkan harusdilakukan secara terus-menerus, dan dibutuhkan sikap disiplin dari siswa.Seseorang dapat disebut disiplin apabila ia melakukan atau mengerjakan sesuatupekerjaan dengan tertib dan teratur dengan waktu dan ketentuan tanpa paksaan darisiapapun. Disiplin tersebut harus terwujud dalam kehidupan keluarga, masyarakat termasuk didalamnya disiplin di sekolah, disiplin belajar dan mengerjakan tugas sekolah. Pentingnya masalah disiplin di sekolah dilakukan oleh unsur yang terkait, seperti terdapat dalam pedoman disiplin sekolah masing-masing yaitu ketaatanperaturan, tata tertib dan norma yang berlaku dilingkungan sekolah, yangdilaksanakan secara sadar dan ikhlas, baik, lahir maupun batin oleh semua unsuryakni Siswa, Guru, Pegawai, Tata Usaha, Kepala Sekolah.

Menurut Djamarah, minat berarti kecenderungan yang menetap dan mengenang beberapa aktivitas. Seseorang yang berminat terhadap aktivitas akan memperhatikan aktivitas itu secara konsisten dengan rasa senang, minat yang dikaitkan dengan pengertian kepribadian dan nilai selalu mengandung unsur afektif atau perasaan, koginitif, dan

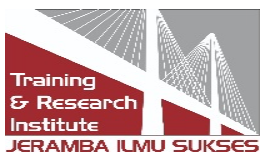


kemauan. Minat dan sikap meliputi penerimaan dan penolakan terhadap sesuatu yang dimensinya berbeda sikap lebih bersifat setuju atau tidak setuju, sedang minat lebih bersifat senang atau tidak senang. Minat dapat menjadi indikator dari kekuatan seseorang di area tertentu dimana ia akan termotivasi untuk mempelajarinya dan menunjukkan kinerja yang tinggi. Siswa yang semenjak awal memiliki minat yang tinggi terhadap mata pelajaran atau jurusan tertentu cenderung memiliki semangat belajar yang tinggi dan berakibat langsung terhadap hasil belajar yang dicapainya. Dengan demikian minat belajar seseorang dapat juga menjadi sebuah indikator pencapaian hasil belajar pada diri seorang siswa. Berdasarkan hasil pengamatan penulis di SMAN 1 Panyabungan Selatan untuk meningkatkan minat belajar Pendidikan Agama Islam peserta didik, diwujudkan dengan disiplin belajar yang berorientasi pada peserta didik artinya guru harus memberi penekanan dan pengalaman secara langsung serta merancang proses belajar mengajar di kelas yang memberi banyak kesempatan kepada peserta didik untuk mengembangkan pengetahuan dan menerapkan hal-hal yang telah dipelajarinya. Pada dasarnya dari tujuan disiplin sekolah adalah memberi dukungan bagi terciptanya perilaku yang tidak menyimpang, mendorong siswa melakukan yang baik dan benar. Namun dalam kenyataannya kedisiplinan, minat belajar dan hasil belajar siswa kelas X dan XI SMA Negeri 1 Panyabungan Selatan sangatlah kurang. Hal ini diperkuat dengan hasil observasi yang menunjukan terdapat 3 siswa bahkan terkadang lebih yang tidak mengikuti pelajaran Pendidikan Agama Islam. Hal ini dikarenakan kurangnya kedisiplinan siswa pada mata pelajaran Pendidikan Agama Islam serta kurangnya minat belajar di sekolah yang mengakibatkan hasil belajar siswa yang kurang optimal. Hasil belajar adalah hasil yang diperoleh berupa kesan-kesan yang mengakibatkan perubahan dalam diri individu sebagai hasil dari aktivitas dalam belajar. Walaupun bukan tujuan utama, tetapi hasil belajar merupakan faktor yang sangat penting dalam melihat apakah pembelajaran sudah terlaksana secara efesien. Dari hasil belajar juga akan diketahui peningkatan mutu pendidikan.

Dari hasil pengamatan awal yang dilakukan penulis di SMA Negeri 1 Panyabungan Selatan, pada kelas X dan XI yang diampu oleh guru yang berbeda, KKM (kriteria ketuntasan minimal) mata pelajaran Pendidikan Agama Islam yang ditetapkan sekolah yaitu unutuk kelas X KKM nya 75,00 dan kelas XI KKMnya 76,00. Apabilajumlah siswa yang nilainya memenuhi KKM sebanyak $50 \%$ atau lebih maka pembelajaran dikatakan berhasil. Sebaliknya, apabila jumlah siswa yang nilainya sudah memenuhi KKM kurang dari 50\% maka pembelajaran dikatakan belum berhasil. Dalam pelaksanaan pengajaran di SMA Negeri 1 Panyabungan Selatan, pencapaian hasil belajarnya dapat dikatakan belum mencapai hasil secara maksimal. Hal ini dapat dilihat dari pencapaian nilai ulangan harian Pendidikan Agama Islam pada semester genap kelas X dan XI masih rendah, di mana masih banyak siswa yang mendapat nilai di bawah nilai batas ketuntasan yaitu sebesar 75,00 untuk kelas X dan 76,00 untuk kelas XI.

Tabel .1 Daftar ketuntasan dan ketidak tuntasan mata pelajaran PAI Siswa kelas X SMAN 1 Panyabungan Selatan

\begin{tabular}{|c|c|c|c|c|c|c|c|}
\hline \multirow{2}{*}{ Kategori } & \multicolumn{5}{|c|}{ Kelas } & \multirow{2}{*}{ Jumlah } & Persentase \\
\cline { 2 - 6 } & XA1 & XA2 & XA3 & XI1 & XI2 & & \\
\hline Tuntas & 12 & 9 & 8 & 9 & 6 & 44 & $43,13 \%$ \\
\hline
\end{tabular}

Published by:

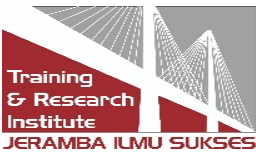




\begin{tabular}{|c|c|c|c|c|c|c|c|}
\hline Tidak Tuntas & 8 & 10 & 12 & 13 & 15 & 58 & $56,86 \%$ \\
\hline
\end{tabular}

Sumber: Dokumen Sekolah SMAN 1 Panyabungan Selatan 2020

Berdasarkan hasil belajar Siswa kelas X SMA Negeri 1 Panyabungan Selatan diketahui bahwa nilai rata-rata ulangan harian pada mata pelajaran PAI, siswa yang telah mencapai ketuntasan hanya mencapai $43,13 \%$ sedangkan selebihnya $56,86 \%$ nilainya belum mencapaiketuntasan belajar. Melihat fenomena tersebut terdapat kondisi yang tidak ideal karena siswa yang mencapai ketuntasan belajar hanya 43,13\%. Diasumsikan kondisi ini, salah satu penyebabnya adalah minat belajar siswa yang masih rendah.Dalam pelaksanaan pengajaran di SMA Negeri 1 Panyabungan Selatan, pencapaian hasil belajarnya dapat dikatakan belum mencapai hasil secara maksimal. Hal ini dapat dilihat dari pencapaian nilai ulangan harian Pendidikan Agama Islam pada semester ganjil kelas XI masih rendah, di mana masih banyak siswa yang mendapat nilai di bawah nilai batas ketuntasan yaitu 76,00 untuk kelas XI.

Tabel .2 Daftar Ketuntasan Dan Ketidak tuntasan Mata Pelajaran PAI Siswa kelas XI SMAN 1 Panyabungan Selatan

\begin{tabular}{|c|c|c|c|c|c|}
\hline \multirow{2}{*}{ Kategori } & \multicolumn{3}{|c|}{ Kelas } & \multirow{2}{*}{ Jumlah } & Persentase \\
\cline { 2 - 4 } & $\begin{array}{c}\text { XI } \\
\text { MIA1 }\end{array}$ & $\begin{array}{c}\text { XI } \\
\text { MIA2 }\end{array}$ & $\begin{array}{c}\text { XI } \\
\text { IIS1 }\end{array}$ & & \\
\hline Tuntas & 8 & 7 & 11 & 26 & $36,62 \%$ \\
\hline Tidak Tuntas & 12 & 13 & 20 & 45 & $63,38 \%$ \\
\hline
\end{tabular}

Sumber: Dokumen Sekolah SMAN 1 Panyabungan Selatan 2020

Sesuai table 2 hasil belajar Siswa kelas XI SMA Negeri 1 Panyabungan Selatan diketahui bahwa nilai rata-rata ulangan harian pada mata pelajaran PAI, siswa yang telah mencapai ketuntasan hanya mencapai $36,62 \%$ sedangkan selebihnya $63,38 \%$ nilainya belum mencapaiketuntasan belajar. Melihat fenomena tersebut terdapat kondisi yang tidak ideal karena siswa yang mencapai ketuntasan belajar hanya 36,62\% dan 63,38\%. Diasumsikan kondisi ini, salah satu penyebabnya adalah minat belajar siswa yang masih rendah.Banyak siswa yang tidak mengikuti pelajaran PAI, selain itu dalam kegiatan belajar mengajar siswa tidak memperhatikan guru ketika sedang mengajar, siswa kurang aktif bertanya dan menjawab pertanyaan yang diajukan oleh guru, serta sering meminjam tugas pada temannya. Kedisiplinan belajar yang baik seharusnya memberikan pengaruh terhadap hasil belajar peserta didik yang baik pula. Disiplin belajaryang baik akan menciptakan kondisi belajaryang kondusif sehinggamemberikan minat kepada peserta didik untuk mengikuti pembelajaran Pendidikan Agama Islam dengan baik.

\section{Tinjauan Literatur}

\section{Disiplin Belajar}

Disiplin dalam kamus besar bahasa Indonesia diartikan sebagai Tata tertib (disekolah, kemiliteran), ketaatan (kepatuhan), kepada peraturan (tata tertib). Secara umum kata disiplin mengandung pengertian sikap yang menjelma dalam prilaku seseorang dengan tujuan agar segala perbuatannya selalu mentaati peraturan atau tata tertib yang berlaku. Menurut Syaiful Bahri Djamarah disiplin adalah suatu tata tertib yang dapat mengatur

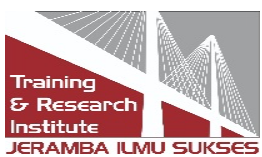


tatanan kehidupan pribadi dan kelompok. Tata tertib itu bukan buatan binatang, melainkan buatan manusia sebagai pembuat dan pelaku.Sedangkan disiplin timbul dari dalam jiwa karena adanya dorongan untuk menaati tata tertib tersebut. Disiplin adalah upaya untuk mengendalikan diri dan sikap mental seseorang atau masyarakat dalam mengembangkan kebutuhan dan ketaatan terhadap peraturan dan tata tertib berdasarkan dorongan dan kesadaran yang muncul dalam hatinya. Dapat disimpulkan bahwa pengertian disiplin adalah perasaan taat dan patuh terhadap nilai-nilai yang dipercaya termasuk melakukan pekerjaan tertentu yang menjadi tanggungjawabnya.

\section{Minat Belajar}

Proses belajar yang dilakukan oleh siswa terhadap suatu mata pelajaran bukan hanya sekedar membaca dan menulis mata pelajaran tersebut. Belajar suatu mata pelajaran harus diikuti dengan minat, dengan adanya minat terhadap mata pelajaran tersebut akan mencapai prestasi yang diinginkan karena minat merupakan salah satu yang ikut menentukan keberhasilan siswa dalam belajar. Beberapa definisi minat menurut para ahli adalah sebagai berikut:

a. Minat adalah kecenderungan yang tetap untuk memperhatikan dan mengenang beberapa kegiatan.

b. Minat adalah kecenderungan dan kegairahan yang tinggi atau keinginan yang besar terhadap sesuatu.

c. Minat belajar adalah tertarik atau terlibat sepenuhnya dengan suatu kegiatan karena menyadari pentingnya kegiatan itu.

d. Minat merupakan kecenderungan pada diri peserta didik yang berhubungan dengan perasaan senang atau tidak senang dan tertarik atau tidak tertarik terhadap mata pelajaran tertentu.

Minat erat sekali hubungannya dengan suka atau tidak suka, tertarik atau tidak tertarik, senang atau tidak senang. Minat tidak tercetus dengan sendirinya, tetapi sesuatu yang terwujud disebabkan pengaruh-pengaruh tertentu seperti guru yang baik serta penguasaan materi pelajaran. Berkaitan dengan mata pelajaran Pendidikan Agama Islam, minat belajar siswa dapat ditunjukakan dengan adanya adanya rasa senang ketertarikan, keseriusan dan keaktifan siswa terhadap mata pelajaran Pendidikan Agama Islam dengan penuh perhatian untuk memperoleh pengetahuan dan mencapai pemahaman mengenai Pendidikan Agama Islam secara maksimal. Hal tersebut dapat ditunjukan dengan adanya partisipasi aktif siswa dalam mengikuti kegiatan belajar mengajar, keseriusan siswa dalam belajar serta kemauan siswa dalam menyelesaikan tugas dengan baik.

\section{Hasil Belajar Siswa}

Hasil belajar merupakan bagian terpenting dalam pembelajaran. Hasil belajar menurut Benyamin Bloom adalah pencapaian bentuk perubahan perilaku yang cenderung menetap dari ranah kognitif, efektif, dan psikomotoris dari proses belajar yang dilakukan dalam waktu tertentu. Menurut Nana Sudjana, hasil belajar adalah hasil yang diperoleh berupa kesan-kesan yang mengakibatkan perubahan dalam diri individu sebagai hasil dari aktivitas dalam belajar. Perubahan dalam tingkahlaku tersebut, merupakan indikator yang dijadikan pedoman untuk mengetahui kemajuan seorang siswa dalam segala hal yang diperoleh disekolah. Dengan demikian hasil belajar tampak sebagai terjadinya perubahan

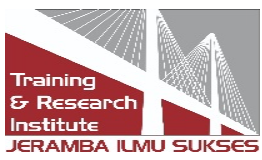


tingkahlaku dankemampuan pada diri siswa yang dapat diamati dalam bentuk perubahan sikap dan keterampilan.Perubahan tersebut dapat juga diartikan sebagai terjadinya peningkatan dan pengembangan yang lebih baik dari sebelumnya.

\section{Pendidikan Agama Islam}

Pendidikan Agama Islam bertujuan untuk meningkatkan keimanan, pemahaman, penghayatan, dan pengalaman peserta didik tentang agama Islam, sehingga menjadi manusia muslim yang beriman dan bertakwa kepada Allah SWT serta berakhlak mulia dalam kehidupan pribadi, bermasyarakat, berbangsa dan bernegara.

Secara Umum, Pendidikan Islam bertujuan untuk meningkatkan keimanan, pemahaman, penghayatan dan pengalaman peserta didik tentang agama Islam, sehingga menjadi manusia muslim yang beriman dan bertakwa kepada Allah SWT serta berakhlak mulia dalam kehidupan pribadi, bermasyarakat, berbangsa dan bernegara. Dari tujuan tersebut dapat ditarik beberapa dimensi yang hendak di tingkatkan dan dituju oleh kegiatan pembelajaran Pendidikan Agama Islam, yaitu :

1. Dimensi keimanan peserta didikterhadap ajaran agama Islam,

2. Dimensi Pemahaman atau penalaran (intelektual) serta keilmuan peserta didik terhadap ajran agama Islam,

3. Dimensi penghayatan atau pengalamanbatin yang dirasakan peserta didik dalam menjalankan ajaran agama Islam,

4. Dimensi pengamalannya, dalam arti bagaimana ajaran Agama Islam yang telah diimani, dipahami, dan mampu menumbuhkan motivasi dalam dirinya untuk menggerakkan, mengamalkan, dan menaati ajaran agama dan nilai-nilainya dalam kehidupan pribadi, sebagai manusia yang beriman dan bertakwa pada Allah SWT, dan merealisasikannya dalam kehidupan bermasyarakat, berbangsa dan bernegara.

\section{Metode Penelitian}

Penelitian ini menggunakan jenis penelitian kuantitatif dengan menggunakan rancangan korelasional. Penelitian korelasional adalah suatu penelitian yang melibatkan tindakan pengumpulan data guna menentukan apakah ada hubungan dan tingkat hubungan antara dua variabel atau lebih. Variabel dalam penelitian ini ada 2 variabel, yaitu 2 variabel bebas dan 1 variabel terikat. Variabel bebas dalam penelitian ini adalah pengaruh disiplin belajar dan minat siswa sedangkan variable terikat dalam penelitian ini adalah hasil belajar siswa kelas X dan XI SMA Negeril Panyabungan Selatan.

\section{Populasi}

Populasi adalah wilayah generalisasi yang terdiri atas objek/ subjek yang memiliki kualitas dan karakteristik tertentu yang di tetapkan oleh peneliti dan ditarik kesimpulannya. Sedangkan menurut Suharsimi Arikunto, populasi adalah keseluruhan subjek penelitian. Dalam hal ini yang menjadi populasi adalah seluruh siswa kelas X dan XI di SMAN 1 Panyabungan Selatan yang berjumlah 152 orang.

Tabel.3 Populasi

\begin{tabular}{|c|c|}
\hline Kelas & Jumlah \\
\hline $\mathbf{X}$ & $\mathbf{7 5}$ \\
\hline
\end{tabular}




\begin{tabular}{|c|c|}
\hline XI & $\mathbf{7 7}$ \\
\hline Jumlah & 152 \\
\hline
\end{tabular}

Sumber Data: Tata Usaha SMAN 1 Panyabungan Selatan, 2020

\section{Sampel}

Sampel adalah sejumlah subjek penelitian sebagai wakil dari populasi sehingga dihasilkan sampel yang mewakili populasi yang dimaksud. Mengingat jumlah populasi yang cukup besar, maka pengambilan sampel dilakukan dengan teknik sampling yang digunakan adalah proportional stratified Random Sampling, yaitu populasi yang dianggap heterogen menurut karakteristik tertentu, di kelompokkan dalam beberapa sub populasi yang ada memilki anggota sampel yang relative homogen.

Untuk mendapatkan jumlah sampel dalam penelitian ini, digunakan rumus yang di kemukakan oleh Slovin dalam Umar.

$$
\begin{aligned}
& \mathrm{n}=\frac{N}{1+N e^{2}} \\
& \mathrm{n}=\frac{152}{1+152.10 \%^{2}} \\
& \mathrm{n}=\frac{152}{2,52} \\
& \mathrm{n}=60,31 \\
& \text { Keterangan: } \\
& \mathrm{n}=\text { Ukuran sampel } \\
& \mathrm{N}=\text { Ukuran Populasi } \\
& \mathrm{e}=\text { Nilai kritis/batas ketelitian yang di inginkan }
\end{aligned}
$$

Berdasarkan rumus tersebut, maka jumlah sampel dalam penelitian ini sebanyak 60 orang siswa. Pengambilan sampel sebanyak 60 orang siswa, yang terdiri dari kelas X dan XI di SMAN 1 Panyabungan Selatan. Sampel tersebut sebagai berikut:

Tabel 4. Jumlah Sampel

\begin{tabular}{|c|r|}
\hline Kelas & \multicolumn{1}{|c|}{ Jumlah } \\
\hline X & $(75 / 152) \times 60=30$ \\
\hline XI & $(77 / 152) \times 60=30$ \\
\hline Jumlah & 60 \\
\hline
\end{tabular}

Sumber Data: Dokumentasi SMAN 1 Panyabungan Selatan, 2020

\section{Tekhnik Analisis Data}

Analisis data merupakan salah satu langkah penting dalam rangka memperoleh temuan-temuan hasil penelitian. Hal ini disebabkan, data akan menuntun kita ke arah temuan ilmiah, bila dianalisis dengan teknik-teknik yang tepat. Data yang belum dianalisis masih merupakan data mentah. Dalam kegiatan penelitian, data mentah akan memberi arti, bila dianalisis dan ditafsirkan.

Dalam penelitian ini teknik yang digunakan merupakan teknik analisis statistik inferensial, yaitu teknik yang mendasarkan pada pemanfatan data yang di peroleh dari suatu sampe lacak, sehingga hasilnya merupakan gambaran ke adaan populasi dari mana sampel acak tersebut diambil. Teknik statistic semacam ini memberikan jaminan bahwa kesimpulan dan penafsiran dibuat dengan tingkat

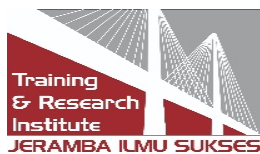


kesalahan yang rendah, biasanya dipakai 0,05 (5\%). Statistik inferensial, (sering juga disebut statistik induktif atau statistik probabolitas) adalah teknik statistik yang digunakan untuk menganalisis data sampel dan hasilnya diberlakukan untuk populasi. Statistik ini akan cocok digunakan bila sampel diambil dari populasi yang jelas dan teknik pengambilan sampel dari populasi itu dilakukan secara random. Statistik ini disebut statistik probabilitas, karena kesimpulan yang diberlakukan untuk populasi berdasarkan data sampel itu kebenarannya bersifat peluang (probability). Suatu kesimpulan dari data sampel yang akan diberlakukan untuk populasi itu mempunyai peluang kesalahan dan kebenarannya (kepercayaan) dan yang dinyatakan dalam bentuk prosentase. Bila peluang kesalahan 5\% maka taraf kepercayaan 95\%, bila peluang kesalahan 1\%, maka taraf kepercayaan 99\%. Peluang kesalahan dan kepercayaan ini disebut dengan taraf signifikansi.

Dalam penelitian ini, untuk analisis data yang digunakan adalah analisis data korelasi dan regresi. Berikut adalah langkah-langkah dalam melaksanakan analisis data dalam penelitian ini:

1) Uji Normalitas Data

Uji normalitas adalah pengujian tentang kenormalan distribusi data.Penggunaan uji normalitas karena pada analisis statistik parametik, asumsi yang harus dimiliki oleh data adalah bahwa data tersebut harus terdistribusi secara normal. Maksud data terdistribusi secara normal adalah bahwa data akan mengikuti bentuk distribusi normal.

Uji normalitas bisa dilakukan dengan dua cara. Yaitu dengan "Normal P-P Plot" dan "Tabel Kolmogorov Smirnov". Yang paling umum digunakan adalah Normal P-P Plot.

Pada Normal P-P Plot prinsipnya normalitas dapat dideteksi dengan melihat penyebaran data (titik) pada sumbu diagonal grafik atau dengan melihat histogram dari residualnya. Dasar pengambilan keputusan:

a. Jika data menyebar di sekitar garis diagonal dan mengikuti arah garis diagonal atau grafik histogramnya menunjukkan pola distribusi normal, maka model regresi memenuhi asumsi normalitas.

b. Jika data menyebar jauh garis diagonal dan/atau tidak mengikuti arah garis diagonal atau grafik histogram tidak menunjukkan pola distribusi normal, maka model regresi tidak memenuhi asumsi formalitas.

\section{2) Uji Heteroskedastisitas}

Uji heteroskedastisitas bertujuan menguji apakah dalam model regresi terjadi ketidaksamaan varians dari residual satu pengamatan ke pengamatan yang lain. Model regresi yang baikadalah yang homoskedastisitas. Jika ada pola tertentu pada grafik scatterplot antara SRESID dan ZPRED seperti titik-titik yang ada membentuk pola tertentu yang teratur (bergelombang, melebar kemudian menyempit), maka mengidentifikasikan telah terjadi heteroskedastisitas. Jika tidak ada pola yang jelas pada grafik scatterplot antara SRESID dan ZPRED, serta titik-titik menyebar di atas dan di bawah angka 0 pada sumbu Y, maka terjadi homoskedastisitas.

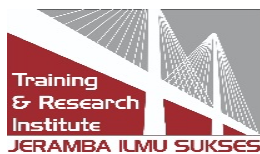


3) Uji Regresi Linear Berganda

Uji regresi ganda merupakan pengembangan dari uji sederhana. Kegunaannya yaitu untuk meramalkan nilai variable terikat apabila variable bebas minimal dua atau lebih. Uji regresi ganda adalah alat analisis peramalan nilai pengaruh dua variable atau lebih terhadap satu variable terikat. Bentuk persam aan regresi ganda :

$\mathrm{Y}=\mathrm{a}+\mathrm{b}_{1} \mathrm{X}_{1}+\mathrm{b}_{2} \mathrm{X}_{2}$

Nilai determinasi Korelasi Ganda $\mathrm{KP}=\mathrm{R}^{2} .100 \%$

Kaidah pengujian : Jika $\mathrm{F}_{\text {hitung }}>\mathrm{F}_{\text {tabel }}$ maka signifikan

$\mathrm{JikaF}_{\text {hitung }}<\mathrm{F}_{\text {tabel }}$ maka tidak signifikan

Selanjutnya perhitungan analisis data dilakukan dengan menggunakan software pengola han data statistik SPSS versi16.

\section{Hasil dan Pembahasan}

\section{Uji Normalitas Data}

Uji normalitas dimaksudkan untuk mengetahui apakah sebarandata berdistribusi normal atau tidak.

Tabel 5. One-Sample Kolmogorov-Smirnov Test

\begin{tabular}{|ll|r|r|r|}
\hline & & \multicolumn{1}{c|}{$\begin{array}{c}\text { Hasil Belajar } \\
\text { Siswa }(Y)\end{array}$} & $\begin{array}{c}\text { Disiplin Belajar } \\
(\mathrm{X} 1)\end{array}$ & $\begin{array}{r}\text { Minat Belajar } \\
(\mathrm{X} 2)\end{array}$ \\
\hline $\mathrm{N}$ & & 60 & 60 & 60 \\
Normal Parameters ${ }^{\mathrm{a}}$ & Mean & 73.4167 & 118.1667 & 118.7500 \\
& Std. Deviation & 5.92407 & 11.75623 & 11.50037 \\
Most Extreme Differences & Absolute & .175 & .227 & .194 \\
& Positive & .175 & .128 & .115 \\
& Negative & -.083 & -.227 & -.194 \\
Kolmogorov-Smirnov $Z$ & & 1.356 & 1.759 & 1.504 \\
Asymp. Sig. (2-tailed) & & .151 & .204 & .122 \\
\hline
\end{tabular}

a. Test distribution is Normal.

Sumber : Hasil Pengolahan Data Primer 2020

Output diatas menjelaskan tentang hasil uji normalitas denganmetode One Sample Komogorov Smirnov. Untuk menentukannormallitas dari data tersebut cukup membaca pada nilai signifikansi(Asymp Sig 2-tailed). Jika signifikansi kurang dari 0,05, makakesimpulannya data tidak berdistribusi normal, tetapi jika nilaisignifikansi lebih dari 0,05, maka data tersebut berdistribusi normal. Darioutput diatas nilai Asymp. Sig (2 tailed) untuk variabel hasil belajar siswa didapat 0,151 artinya $>0,05$,kemudian untuk variabel disiplin belajar memiliki nilai Asymp. Sig ( 2 tailed) 0,204 $>0,05$ dan yang terakhir nilai minat belajar siswa memiliki nilai Asymp. Sig ( 2 tailed) $0,122>0,05$ sehingga dapat disimpulkan bahwa ketiga variabel yang penulis teliti memiliki nilai Asymp. Sig (2 tailed) di atas dari 0,05 sehingga dapat disimpulkan bahwa data berdistribusi secara normal.

\section{Uji Heteroskedastisitas}

Published by:

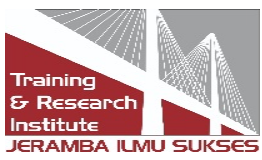


Uji Heteroskedastisitas bertujuan menguji apakah dalam model regresi terjadi ketidaksamaan varian dari residual satu pengamatan kepengamatan yang lain. Jika varian dari residual satu pengamatan ke pengamatan lain tetap, maka disebut homoskedastisitas dan jika berbeda disebut heteroskedastisitas.Model regresi yang baik adalah yang homoskedastisitas atau tidak terjadi heteroskedastisitas. Untuk mendeteksi ada atau tidaknya heteroskedastisitas dapat dilakukan dengan uji Scatterplot. Jika titik titik yang ada pada kolom menyebar dan tidak membentuk suatu pola maka dikatakan tidak terjadi heterskedastisitas dan sebaliknya dan dapat dilihat pada gambar 4.1 di bawah ini :

\section{Gambar 1. Scatterplot}

\section{Scatterplot}

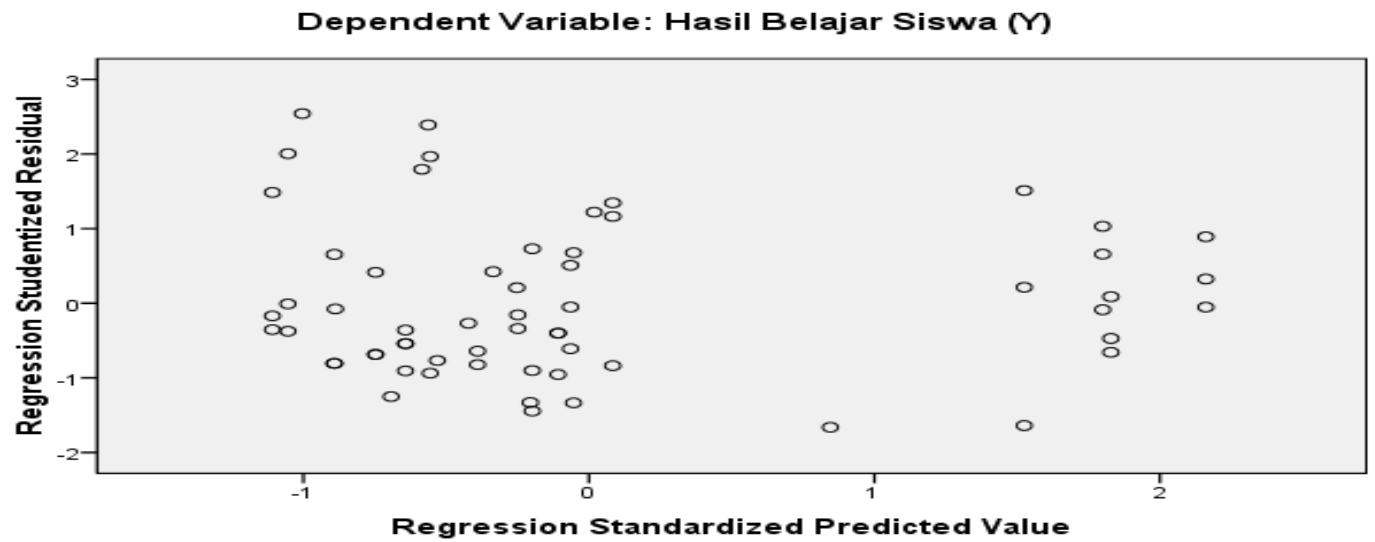

Sumber : Hasil Pengolahan data Primer Tahun 2020

Berdasarkan analisis data untuk uji heteroskedastisitas sebagaimana terlihat pada gambar 1 di atas, terlihat bahwa titik - titik yang ada pada kolom menyebar dan tidak membentuk suatu pola sehingga dapat disimpulkaan bahwa pada penelitian ini tidak terjadi kasus heteroskedastisitas. Dengan demikian analisis regresi dapat dilakukan karena uji heteroskedastisitas sudah memenuhi syarat.

\section{Uji Hipotesis}

\section{Analisa Korelasi Berganda}

a. X (Disiplin belajar dan minat belajar) terhadap Y1 (Hasil belajar siswa) Analisis korelasi berganda berfungsi untuk mengetahui keeratanhubungan lebih dari dua variable, dalam hal ini Kegiatan PrDisiplin belajar $\left(\mathrm{X}_{1}\right)$ dan Minat belajar $\left(\mathrm{X}_{2}\right)$ terhadap Hasil Belajar SiswaSMA N 1 Panyabungan Selatan (Y).

Tabel 6. Hasil Analisa Korelasi Berganda

Model Summary

\begin{tabular}{|l|r|r|r|r|r|}
\hline Model & $\mathrm{R}$ & $\mathrm{R}$ Square & Adjusted R Square & Std. Error of the Estimate & Durbin-Watson \\
\hline 1 & $.680^{\mathrm{a}}$ & .544 & .414 & 1.57566 & 1.767 \\
\hline
\end{tabular}
a. Predictors: (Constant), Minat Belajar (X2), Disiplin Belajar (X1)
b. Dependent Variable: Hasil Belajar Siswa (Y)

Sumber : Hasil Pengolahan data Primer Tahun 2020

Published by:

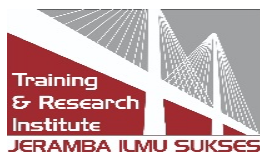


Menurut Sugiyono pedoman untuk memberikan interpretasi koefisienkorelasi sebagai berikut:

$$
\begin{aligned}
0,00-0,199 & =\text { sangat rendah } \\
0,20-0,399 & =\text { rendah } \\
0,40-0,599 & =\text { sedang } \\
0,60-0,799 & =\text { kuat } \\
0,80-1,000 & =\text { sangat kuat }
\end{aligned}
$$

Berdasarkan table di atas dapat diketahui bahwa koefisian dariPengaruh Disiplin Belajar dan Minat Belajar terhadap Hasil Belajar Siswa SMA N 1 Panyabungan Selatan adalah 0.680. hasil ini jikadi interpretasikan berdasarkan tabel diatas menunjukkan hubungan yang kuat antara kedua variabel independen tersebut terhadap Hasil Belajar SiswaSMA N 1 Panyabungan Selatan.

\section{Hasil Analisis Regresi Linear Berganda}

Analisis regresi berganda digunakan untuk melihat pengaruh disiplin belajar dan minat belajar terhadap hasil belajar siswa pada SMA N 1 Panyabungan Selatan dan sekaligus dalam rangka membuktikan hipotesis yang diajukan dalam penelitian. Persamaan regresi linear berganda berguna untuk melihat pengaruh dari masing-masing variabel bebas terhadap variabel terikat dengan menggunakan pendekatan Ordinary Least Square (OLS).

\section{Pengaruh disiplin belajar dan minat belajar Terhadap Hasil Belajar}

Hipotesis yang dikembangkan dalam penelitian ini adalah disiplin belajar dan minat belajar berpengaruh terhadap hasil elajar siswa pada SMA N 1 Panyabungan Selatan. Untuk melakukan pengujian ini digunakan analisa regresi linier berganda. Uji $t$ bertujuan untuk untuk mengetahui apakah dalam modelregresi variabel independen (X) secara parsial berpengaruh signifikan terhadap variabel dependen (Y1). Dengan kriteria Pengujian

Ho diterima jika thitung $<$ ttabel / -thitung $>$-ttabel

\begin{tabular}{|c|c|c|c|c|c|c|c|c|}
\hline \multirow{2}{*}{\multicolumn{2}{|c|}{ Model }} & \multicolumn{2}{|c|}{$\begin{array}{l}\text { Unstandardized } \\
\text { Coefficients }\end{array}$} & \multirow{2}{*}{$\begin{array}{c}\begin{array}{c}\text { Standardized } \\
\text { Coefficients }\end{array} \\
\text { Beta } \\
\end{array}$} & \multirow[t]{2}{*}{$\mathrm{t}$} & \multirow[t]{2}{*}{ Sig. } & \multicolumn{2}{|c|}{ Collinearity Statistics } \\
\hline & & B & Std. Error & & & & Tolerance & VIF \\
\hline 1 & (Constant) & 95.460 & 7.535 & & 12.669 & .000 & & \\
\hline & Disiplin Belajar (X1) & .252 & .231 & .500 & 3.091 & .020 & .871 & 3.991 \\
\hline & Minat Belajar (X2) & .465 & .236 & .126 & 4.275 & .004 & .871 & 3.991 \\
\hline
\end{tabular}

Ho ditolak jika thitung $>$ ttabel $/$ - thitung $<$-ttabel

Hasil analisa regresi liner berganda dapat dijelaskan pada Tabel 7. berikut:

Tabel 7. Hasil Analisa Regresi Berganda

\section{Coefficients $^{a}$}

a. Dependent Variable: Hasil Belajar Siswa (Y)

Sumber:Hasil Pengolahan Data Primer, 2020

Berdasarkan Tabel 7 terlihat bahwa nilai koefisien regresi untuk masing-masing variabel diatas dapat disubtitusikan ke dalam persamaan regresi linear berganda sebagai berikut : $\mathrm{Y}=95,460+0,252 \mathrm{X}_{1}+0,465 \mathrm{X}_{2}$

Dari persamaan tersebut dapat dijelaskan bahwa:

Pada persamaan regresi diatas menunjukkan nilai konstanta sebesar 95,460 hal ini menyatakan bahwa nilai variabel hasil belajar siswa pada SMAN 1 Panyabungan Selatan.

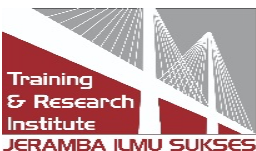


Koefisien $\mathrm{b}$ dinamakan koefisien arahregresi yang menyatakan perubahan rata-rata variabel Y untuk setiapperubahan variabel X sebesar satu satuan. Perbuhan ini merupakan pertambahan bila $b$ positif dan penurunan bila $b$ negatif. Nilai angkakoefisien regresi 0.252 menyatakan bahwa setiap penambahan $1 \%$ nilaivariabel disiplin belajar $\left(\mathrm{X}_{1}\right)$ akan meningkatkan hasil belajar siswa pada SMA N 1 Panyabungan Selatan (Y)sebesar 0.252, begitu juga dengan nilai angkakoefisien regresi $0.465\left(\mathrm{X}_{2}\right)$ menyatakan bahwa setiap penambahan $1 \%$ nilaivariabel minat belajar $\left(\mathrm{X}_{2}\right)$ akan meningkatkan hasil belajar siswa pada SMA N 1 Panyabungan Selatan (Y)sebesar 0.465.

Melihat output SPSS pada tabel diatas pada uji t danmembandingkan thitung dengan ttabel yang diperoleh dari tabel $t$ denganperhitungan degree of freedom $(\mathrm{df})$ sebagai berikut : $\mathrm{df}=\mathrm{n}-\mathrm{k}-1$ makadf $=60-2-1=57$ dimana $\mathrm{n}=$ jumlah sampel dan $\mathrm{k}=$ jumlah variabelindependen. Selanjutnya setelah diketahui nilai df 57 , penulis meihattabel statistik pada tingkat sig 0.05 sehingga nilai ttabel yang didapatsebesar 2.75

\section{Hipotesis 1: Disiplin Belajar Terhadap Hasil Belajar}

$\mathrm{H} 0=$ Disiplin Belajar tidak mempunyai pengaruh terhadap Hasil Belajar

$\mathrm{Ha}=$ Disiplin Belajarmempunyai pengaruh terhadap Hasil Belajar

Hasil uji t Disiplin belajar $\left(\mathrm{X}_{1}\right)$ terhadap Hasil Belajar $(\mathrm{Y})$ menunjukkan nilai sig 0.020 nilai lebih kecil dari $0.050(0.020<0.050)$. thitung lebih besar dari ttabel $(3,091>2,75)$ dengan koefesienregresi sebesar $2.52 \%$. Hal ini berarti bahwa $\mathrm{H} 0$ ditolak dan Haditerima, secara parsial disiplin belajar memiliki hubungan positifdan berpengaruh signifikan dengan hasil belajar siswa pada SMA N 1 Panyabungan Selatan.

\section{Hipotesis 2: Minat Belajar Terhadap Hasil Belajar}

$\mathrm{HO}=$ Minat Belajar tidak mempunyai pengaruh terhadap Hasil Belajar

$\mathrm{Ha}=$ Minat Belajar mempunyai pengaruh terhadap Hasil Belajar

Hasil uji t Minat belajar $\left(\mathrm{X}_{2}\right)$ terhadap Hasil Belajar (Y) menunjukkan nilai sig 0.004 nilai lebih kecil dari $0.050(0.004<0.050)$. thitung lebih besar dari ttabel $(4,275>2,75)$ dengan koefesienregresi sebesar $4.65 \%$. Hal ini berarti bahwa $\mathrm{H} 0$ ditolak dan Ha diterima, secara parsial minat belajar memiliki hubungan positif dan berpengaruh signifikan dengan hasil belajar siswa pada SMA N 1 Panyabungan Selatan.

\section{Hipotesis 3: Disiplin belajar dan Minat Belajar Terhadap Hasil Belajar}

$\mathrm{HO}=$ Disiplin belajar dan Minat Belajar tidak mempunyai pengaruh terhadap Hasil Belajar

$\mathrm{Ha}=$ Disiplin belajar dan Minat Belajar mempunyai pengaruh terhadap Hasil Belajar Hasil uji fDisiplin belajar dan Minat belajar $\left(\mathrm{X}_{1}\right.$ dan $\left.\mathrm{X}_{2}\right)$ terhadap Hasil Belajar (Y) menunjukkan nilai sig 0.012 nilai lebih kecil dari $0.050(0.012<0.050)$. f hitung lebih besar dari f tabel $(4,802>3,153)$. Hal ini berarti bahwa $\mathrm{H} 0$ ditolak dan Ha diterima, secara simultan disiplin belajar dan minat belajar secara bersama-sama memiliki hubungan positif dan berpengaruh signifikan dengan hasil belajar siswa pada SMA $N 1$ Panyabungan Selatan.

\section{Kesimpulan}

Berdasarkan penelitian dan analisis yang peneliti lakukan denganmenggunakan alat bantu program SPSS 16.0, maka peneliti dapatmenyimpulkan bahwa :

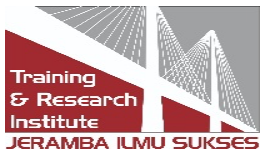


1. Hipotesis yang diajukan dalam penelitian ini adalah untuk mengetahuiadanya pengaruh disiplin belajar terhadap hasil belajar siswa pada SMA N 1 Panyabungan Selatan. Nilai angka koefisienregresi 0.252 menyatakan bahwa setiap penambahan $1 \%$ nilai variabel Disiplin Belajar $\left(\mathrm{X}_{1}\right)$ akan meningkatkan hasil belajar siswa pada SMA N 1 Panyabungan Selatan (Y) sebesar 0.252.Hasil uji t Disiplin Belajar $\left(\mathrm{X}_{1}\right)$ terhadap hasil belajar siswa pada SMA N 1 Panyabungan Selatan (Y)menunjukkan nilai sig 0.020 nilai lebih kecil dari $0.050(0.020<$ 0.050).thitung lebih besar dari ttabel $(3,091>2,75)$ dengan koefesien regresisebesar $2.52 \%$. Hal ini berarti bahwa H0 ditolak dan Ha diterima, secaraparsial Disiplin Belajar memiliki hubungan positif dan berpengaruhsignifikan dengan hasil belajar siswa pada SMA N 1 Panyabungan Selatan.

2. Hipotesis yang diajukan dalam penelitian ini adalah untuk mengetahui adanya pengaruh minat belajar terhadap hasil belajar siswa pada SMA N 1 Panyabungan Selatan. Nilai angka koefisien regresi 0.465 menyatakan bahwa setiap penambahan $1 \%$ nilai variabel Minat Belajar $\left(\mathrm{X}_{2}\right)$ akan meningkatkan hasil belajar siswa pada SMA N 1 Panyabungan Selatan (Y) sebesar 0.465. Hasil uji t Minat Belajar $\left(\mathrm{X}_{2}\right)$ terhadap hasil belajar siswa pada SMA N 1 Panyabungan Selatan (Y) menunjukkan nilai sig 0.004 nilai lebih kecil dari $0.050(0.004<0.050)$. t hitung lebih besar dari t tabel $(4,275>2,75)$ dengan koefesien regresi sebesar $4.65 \%$. Hal ini berarti bahwa $\mathrm{H} 0$ ditolak dan Ha diterima, secara parsial Minat Belajar memiliki hubungan positif dan berpengaruh signifikan dengan hasil belajar siswa pada SMA N 1 Panyabungan Selatan.

3. Hipotesis yang diajukan dalam penelitian ini adalah untuk mengetahui adanya pengaruh disiplin belajar dan minat belajar terhadap hasil belajar siswa pada SMA N 1 Panyabungan Selatan. Hasil uji f Disiplin Belajar $\left(\mathrm{X}_{1}\right)$ dan Minat Belajar $\left(\mathrm{X}_{2}\right)$ terahadap hasil belajar siswa pada SMA N 1 Panyabungan Selatan (Y) menunjukkan nilai sig 0.012 nilai lebih kecil dari $0.050(0.012<0.050)$. f hitung lebih besar dari $\mathrm{f}$ tabel $(4,802>3,153)$. Hal ini berarti bahwa $\mathrm{H} 0$ ditolak dan $\mathrm{Ha}$ diterima, secara simultan Disiplin Belajar dan Minat Belajar memiliki hubungan positif dan berpengaruh signifikan dengan Hasil Belajar Siswa pada SMA N 1 Panyabungan Selatan.

\section{Referensi}

Djamarah, Guru Dan Anak didik dalam Interaksi edukatif Suatu Pendekatan Teoritis Psikologis, edisi revisi, cet. III, (Jakarta: PT. Rineka Cipta, 2005)

Heri Tohari dkk,Al-Qur'an Medina Terjemahan dan materi tentang Akhlak mulia,Kementrian Agama RI, (Bandung: PT. Madina Raihan Makmur, 2013) Husain Umar, Metode Penelitian untuk skiripsi dan tesis Bisnis, ( Jakarta: PT. Raja Grafindo Persada, 2011)

Imam Ghozali, Aplikasi Analisis Multivariate dengan Program SPSS,(Semarang: Undip,2013)

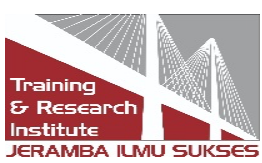


Muhibbin syah ,Psikologi Belajar, (Jakarta: PT Raja Grafindo,2007)

Moentoyah, Aspek-aspek Psikologi dalam Kesulitan Belajar pada Anak dan Remaja, (Semarang: Seminar MakalahKesehatan Jiwa. 2003)

Muhaimin ,Pradigma Pendidikan Islam, (Bandung: Rosda Karya, 2004)

Nana Sudjana, Penilaian Hasil Proses Belajar Mengajar.Cet.11.( Bandung: PT Remaja Rosdakarya,2006)

Pusat Bahasa Departemen Pendidikan Nasional, Kamus Besar Bahasa Indonesia, (Jakarta: Balai Pustaka, 2005)

Purwanto, Evaluasi Hasil Belajar, (Yoyakarta: Pustaka Belajar, 2009)

Shochib Muhammad, Pola Asuh Orang Tua Dalam Membantu anak Mengembangkan DisiplinDiri, (Jakarta: PT. Rineka Cipta,2000)

Slameto.Belajar dan factor- faktor yang mempengaruhinya, (Jakarta: PT Asdi Maha Satya, 2003)

Syaiful Bahri Djamarah, Psikologi Belajar, ( Jakarta: PT. Rineka Cipta, 2008) , Rahasia Sukses Belajar, (Jakarta: Rineka Cipta, 2008)

Sugiyono, Metode penelitian kuantitatif, kualitatif dan $R \& D$, (Bandung: Alfabeta, 2014) 